CIRCULAR OF INFORMATION, NO. I3.

$$
\text { UNIVERSITY OF Missouri }
$$

College of Agriculture and Mechanic Arts Agricut tural Experiment Station

\title{
Agriculture in the Public Schools
}

\section{PLANT PROPAGATION}

\author{
Some Phases of Practical Horticulture Adapted to Use \\ in the Public Schools
}





\section{Agriculture in the Public Schools}

\section{PLANT PROPAGATION}

\section{Some Phases of Practical Horticulture Adapted to Use in the Public Schools}

By W. L. Howard, B. Agr., B. S., Assistant in Horticulture

As a preliminary step to the systematic teaching of Agriculture and Horticulture in the public schools, the pupils may be given some valuable lessons in several of the useful horticultural operations during the school year, even under the present arrangement of studies. In the graded schools where elementary biology and botany are taught, the work will be all the easier because these subjects are so closely allied to Agriculture and Horticulture. Perhaps we should define what is meant in this Bulletin by "Agriculture" and "Horticulture." Broadly speaking, the former embraces the latter, but in the sense the terms are here used, Agriculture has to do with animal husbandry and the grain and grass crops, while Horticulture is chiefly concerned with orchard and garden crops, forestry, and landscape architecture. It should be re- 
membered that the above definitions are only general for both subjects and, also, that they merge one into the other and that no sharp line can be drawn between them.

All children-both young and old-are interested in the propagation of plants and this work is especially adapted to the schoolroom, and can be carried on in most school buildings throughout the entire school year, but especially well during the spring months. Whatever season the work in propagation is to be begun, it is well for the teacher to make some preliminary preparations during the first month of school in the early autumn. The best and surest way of getting the pupils interested is to rely upon their inherent, native euriosity. This may be aroused by preparing some window boxes at the beginning of school and planting in them either flower or garden seeds or potted plants. Of course if the room is not heated by furnace or steam or some such device whereby the temperature may be kept above thirty-five or forty degrees, Fahrenheit, it would be useless to set out green-house plants to remain all winter.

However, under any circumstances, something may be found that will live for at least three months, but the success of the undertaking will depend on the tact, intelligence and ingenuity of the teacher during this time. As the plants unfold their leaves and perhaps begin to flower and fruit, the teacher will be besieged with questions which must be answered faithfully, sympathetically and patiently. Do not profess to know everything, but study with the pupils and endeavor to guide them into knowledge by allowing them to find out for themselves.

Once an interest in plants has been aroused it will 
be time to begin some systematic work in propagation, but do not begin until at least a few of the pupils show that they want it. Do not make the mistake of trying to force unwilling hands into the work, for it must be a pastime or recreation and not a task. And further, their interest in the work must keep them at it, but it must be always borne in mind that the workers will require kindly and sympathetic guidance at all times. This is all that is necessary to a successful and profitable year's work in an interesting line of Horticulture, viz.-Plant Propagation.

But how is one to actually begin, and carry out all of this work which is to be something entirely new in many of the schools? It is the purpose of this Bulletin to answer this question in some detail.

\section{THE BEGINNING OF THE WORK.}

Prepare at least two window boxes for the school room. Make them six or eight inches deep, six to twelve inches wide and as long as the width of the window frame on the inside of the room. Secure the boxes to the window sills-inside of the room, of course-so that there will be no danger of their tumbling down. If possible, place one box at a north window and another on the south or west side of the room. For the purposes which the boxes will be used, it is less desirable to have one at an east window although one would be fairly successful there.

Fill the boxes to within an inch of the top with rich, black garden soil, mixing with it some sand or well rotted manure. An inch or two of thoroughly rotted 
manure or decayed chips from the wood yard, would be very desirable as a top dressing, as this would not only prevent the soil from baking after watering, but would furnish much food for the plants. The sand mixed with the soil would improve its physical condition by rendering it more porous, thus admitting of a

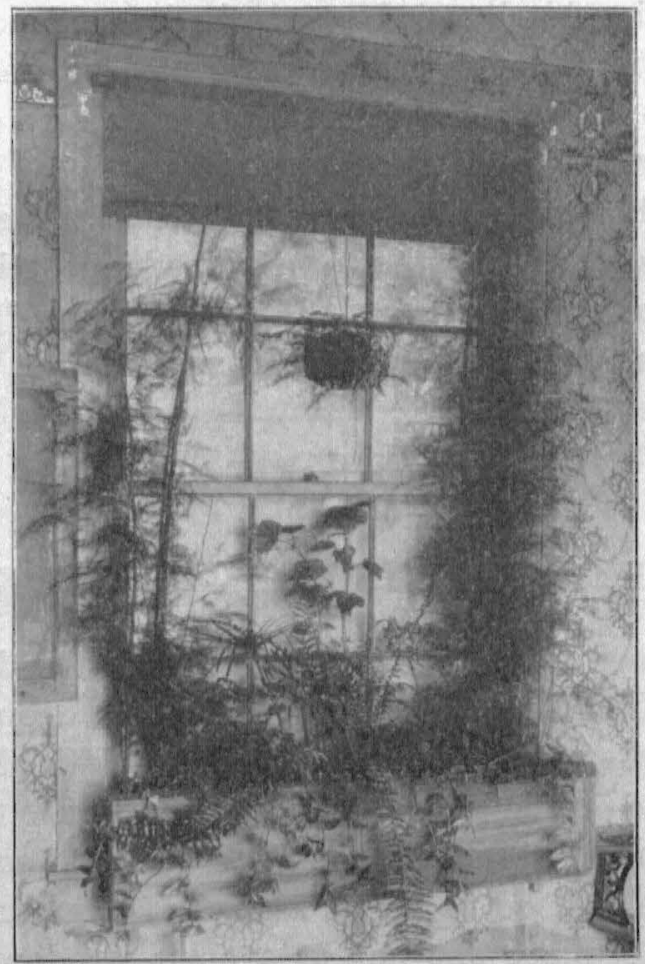

Fig. 1.-Window box for a north window.

freer circulation of air and moisture, both of which are very essential to plant growth.

If the heating system is such that the room can be kept above the freezing point at night throughout winter, the boxes may be planted with such things as 
will continue to grow all the year. In the north window where no sunlight will enter, may be planted ferns, begonias, umbrella plants, etc. See Fig. 1. In the south and west windows there will be a long list of things to select from, in fact taking most any kind of flowering or foliage plant that may be convenient, such as : geraniums, wandering Jew, verbenas, coleus, nasturtiums, lantanas, cigar plants, etc. Cypress, maurandia and like vines at the ends and trained to climb up

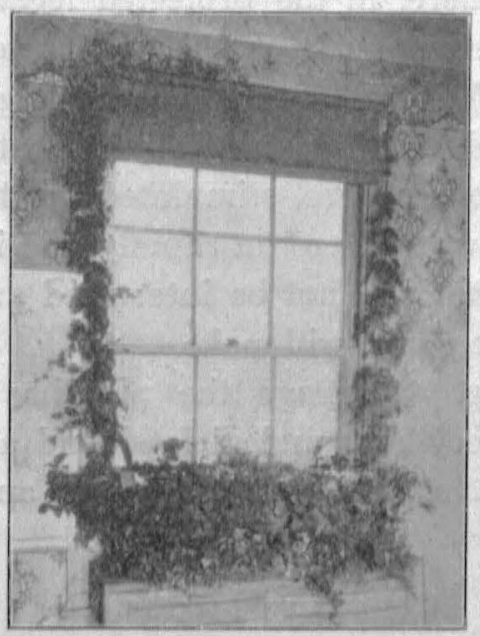

Fig. 2.-Window box for a south or west window.

the wall, would add much to the attractiveness of the boxes. See Fig. 2.

If the room cannot be kept several degrees above the freezing point at night during the winter, only some very temporary plants should be set in the boxes. Geraniums may be grown in the fall and at the approach of cold weather, cease watering for a few days and then dig them up, leaving as much soil as will cling to the roots, and store them away in a box of soil 
(covering only the roots) in a dry cellar or basement room where they will not freeze. In early spring when danger of freezing in the room is over, reset them in the boxes and if all goes well they will soon be in leaf and flower.

On some warm day in late winter when the ground is not frozen, make an excursion to the woods with the class. If possible visit some stream of water either large or small, and scramble among the rocks and brush along its banks and dig into the deep, rich leaf mould where, in the protected locations, a number of mysterious roots, bulbs and rhizomes (underground stems), have begun to grow. Dig out a few of each kind and set them in the propagating bench in the school room. Here, stimulated by the warmth of the room, growth will go on rapidly and it is a morose soul indeed that will not be interested and curious to know what the plants will make.

In spring, encourage the planting of a school garden. School boys and girls should also have gardens at home containing both flowers and vegetables.

\section{METHODS OF PROPAGATION.}

There are several ways of propagating plants, viz., from seeds, cuttings, layering, grafting and budding. There are several other methods to be sure, but they are all modifications or special adaptations of the above.

By SeEds.-Every one knows at least something about how to produce plants from seeds, but it is not universally known that many kinds of seeds require 
special treatment before they will germinate. Corn, wheat, and most of the garden seeds will sprout easily in the proper season, in a few days after being planted if the soil is warm and moist, but those seeds having hard or otherwise peculiar coats, are much more diffcult to germinate. Peach, plum and cherry seeds, as well as walnuts and hickory nuts, must have their shells bursted before germination can go on. We plant these seeds in the autumn so that they may absorb water which freezes in the winter and the hard coats are broken open. Some seeds like those of the honey locust and coffee bean trees, have coverings of a tough, gelatinous substance. These are broken but slowly, even by freezing. With this class of seeds it is often necessary to use boiling water to dissolve the coats. Very small, flinty-covered seeds like the raspberry, are sometimes treated with strong vinegar which partially eats away the covering.

No seed can grow without having a proper amount of heat, air and moisture. Most seeds do best with a temperature between seventy and eighty degrees, Fahrenheit, although many will germinate readily when several degrees warmer, and a few will make a very good growth in a cooler temperature.

Submerge beans or peas in water. They will swell and perhaps burst, but they will make no growth because the air is excluded. Dry seeds, all know, will never grerminate until brought in contact with moisture.

It is an easy matter to furnish air and water to seed beds and growing plants, but for nearly half of the year it is a problem how to furnish artificial heat. Aside from heated rooms two principal methods are employed for furnishing extra heat. The one in most 
general use is the hotbed. This is made out of doors, the best location being the south side of a building or a high board fence, in full view of the sun. To make a hotbed, dig a rectangular pit in the ground, four by six feet, and eighteen inches deep. Set a small post in each corner to which to attach the frame. The long way of the bed should be north and south. To give a good slope to the bed cover, the north end of the frame should be a foot high while the south end should be only eight inches in height and the side pieces made tapering to fit. Fill the pit with fresh manure from a horse barn, manure that has not been exposed to the weather. Over this manure spread a layer of rich soil five or six inches deep. This soil should be made of a mixture of good garden soil, rotted sod and thoroughly rotted manure. A few shovelsful of sand mixed in would be a good thing but it is not essential. Cover the bed with a sash made for the purpose, on the order of a window sash. See Fig. 3, a. Water the bed thoroughly so that the manure is wet down. In four or five days the manure should begin to ferment and give off heat. Plunge a thermometer in the soil and when the temperature gets down to about ninety degrees, F., the seeds may be sown. A bed of this description may be made in March and vegetables like lettuce, radishes, spinach, cress, etc., be ready for table use by the time it will do to sow the earliest seeds in the garden in the spring. It must be remembered that the hotbed will require regular watering everyday or two depending on the state of the weather. Also the growing plants must have an abundance of fresh air. Every day about the middle of the forenoon, if the air is not cold enough to freeze the plants, the south end of the sash should be propped 
up a few inches. On warm, sunny days the sash may be left up until the middle of the afternoon. If severely cold weather is expected, the outside of the frame should be banked up with manure or earth and the sash covered with manure, a board cover, or a mat of some kind.

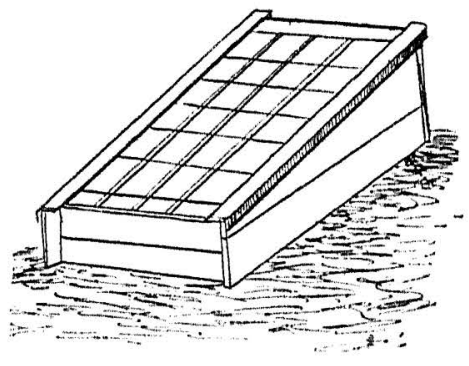

a

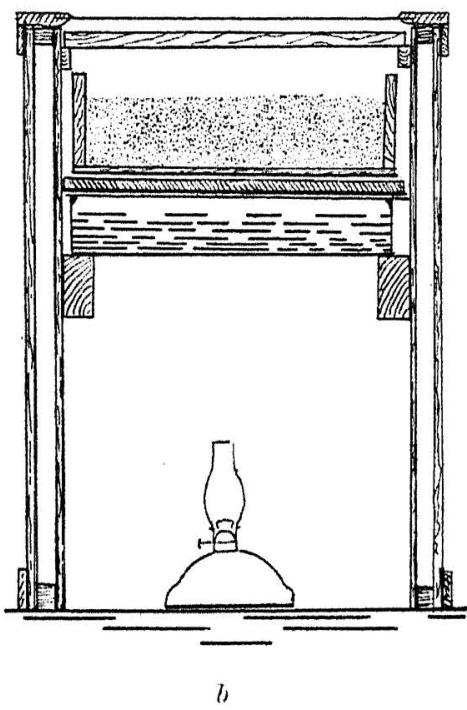

Fig. 3.-(a) A hotbed; (b) sectional view of a propagating oven.

Temporary hotbeds may be made at home or at school by using a large goods box in which the manure and soil are placed. This, however, by being above ground would lose the heat quicker than the one described above, and consequently could not be used so early in the season. Radishes grow to perfection in twenty-seven days after planting the seed.

After danger of severe freezes is past, a much cheaper cover for the bed may be made by tacking to a board frame a sheet of thin cloth which has been soaked in linseed oil; new domestic is good for this purpose. A cover should admit as much sunlight as 
possible but the twelve or fifteen panes of glass required to make the sash would be rather expensive, while a cloth cover could be made for a few cents. By being oiled the cloth admits the light better and also turns the water.

Another device for supplying bottom heat is an inexpensive wooden oven, a sectional diagram of which is shown in Fig. $3, b$, the heat being supplied by a common oil lamp. It is a glass covered box thirty inches high and $22 \times 22$ inches square, outside measurements. The walls should be double so as to better hold the heat. The interior arrangement should consist of a sheet-iron pan three or four inches deep, held in position just over the lamp and filled with water. A sheet of zinc should be laid over the pan and on this may rest a shallow box of sand or soil which is to receive the seeds or cuttings. For winter use it may be necessary to have a board cover to fit in snugly above the plant box, just before the glass top is closed. During the daylight it will usually be warm enough to discard the wooden cover, the glass top being sufficient protection and will let in the light. This lid must be propped up whenever warm enough, in order to air the plants. A propagating oven like the above should be kept indoors.

There are a large number of plants which the horticulturist can not reproduce from seeds for the reason that they will not "come true." This is especially the case with forms under a high state of cultivation like most of the orchard fruits and some of the flowers. After being cultivated and given special attention for a few generations it is the nature of most plants to undergo changes and the cultivator takes advantage of this variability to select the new forms that 
best suit his purposes and ideas, and propagates from them. Thus new types are produced, but unfortunately, where great variation has occurred and highly improved fruit, for example, has been secured, the horticulturist knows from experience that it will not come true from the seed, so some other method of propagation is necessary; and for this reason the practice of budding, grafting, etc., grew up. For the same reasons, largely, flowers like the geranium and rose are

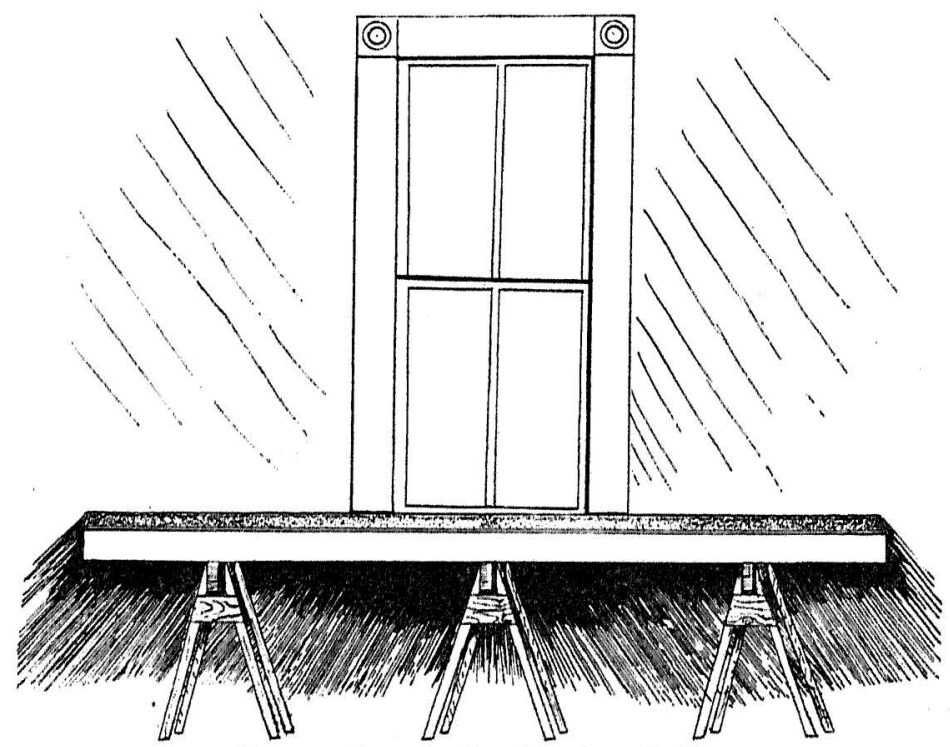

Fig. 4.-Propagating bench or bed.

not grown from seeds but are reproduced from cuttings and layers. Many of the flowers root so readily from cuttings that this method is a much quicker one for reproduction than from seeds, and from the continued disuse of the function of seed production, plants occasionally almost entirely lose their habit of forming seeds. The common Irish potato is a good example. The potato tubers are not seeds at all, but are special 
enlargements of under-ground stems, not roots, and the so-called "eyes" scattered over them are true buds. So that when we plant pieces of potato tubers in spring - each one containing one or more "eyes"-we are in reality planting out cuttings of the potato plant, and the reason these cuttings do not have to be planted in wet sand like other cuttings, is that the pieces of potato are full of water and rich plant food which enable the young plants to live until they form roots to feed from the soil.

\section{PROPAGATING BENCH OR BED.}

A propagating bench, or bed, is generally filled with sand and used for starting seeds and rooting cuttings. A propagating bed would be well adapted to use in a school room. The bed is made by preparing a shallow box five or six inches deep, three feet wide and any convenient length to suit the room. Of course it should be in front of a window where it can get as much sunlight as possible. If the arrangement of the room will admit of it, the bed may be as long as ten feet for a single window, and may rest on common carpenter's trestles. See Fig. 4. Filled with sand to within an inch of the top and thoroughly wet, the bed will be very heavy and should, therefore, be firmly supported.

\section{PROPAGATING FROM CUTTINGS.}

A cutting is a piece of a plant which has been cut off to plant in the soil, sand, or water, for it to grow. 
Cuttings may be made from stems, leaves and roots. When made from stems both hard-wood and softwood are employed. Hard-wood cuttings are prepared from dormant wood that is one year old. Greenwood cuttings are made from the stems of plants while in their green or growing condition.

More than half of the thousands of cultivated plants are propagated principally-often wholly-
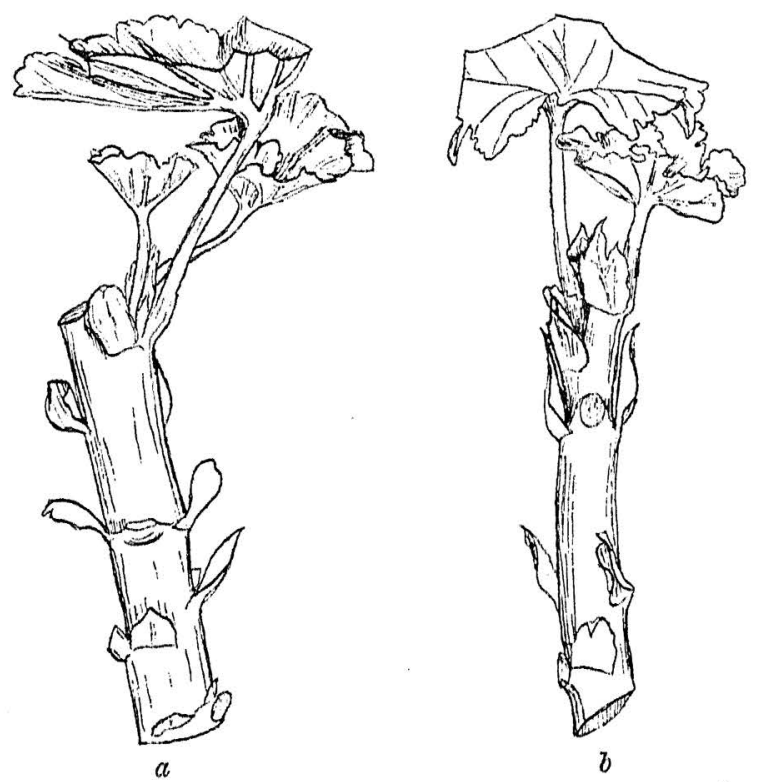

Fig. 5.-(a) A geranium cutting; (b) a geranium cutting with a terminal bud.

from cuttings. Out of this number comparatively few are multiplied from hard-wood cuttings, the great majority being from green or succulent plants.

In the school room the cutting bench may be provided. In the home may be used flat boxes filled with sand and kept sitting near a window.

A few common plants adapted to propagation from cuttings both at home and at school are: Ge- 
ranium, coleus, wandering Jew, rose, lantana, heliotrope, cigar plant, chrysanthemum, alternanthera, sweet alyssum, double petunia and begonia. In making the cuttings it is best to get them ready to plant in the sand bed as quickly as possible after they have been cut from the parent plant. If the material has to be carried some distance or it is not possible to make the finished cuttings ready for planting immediately, they may be dropped in a pan of water or

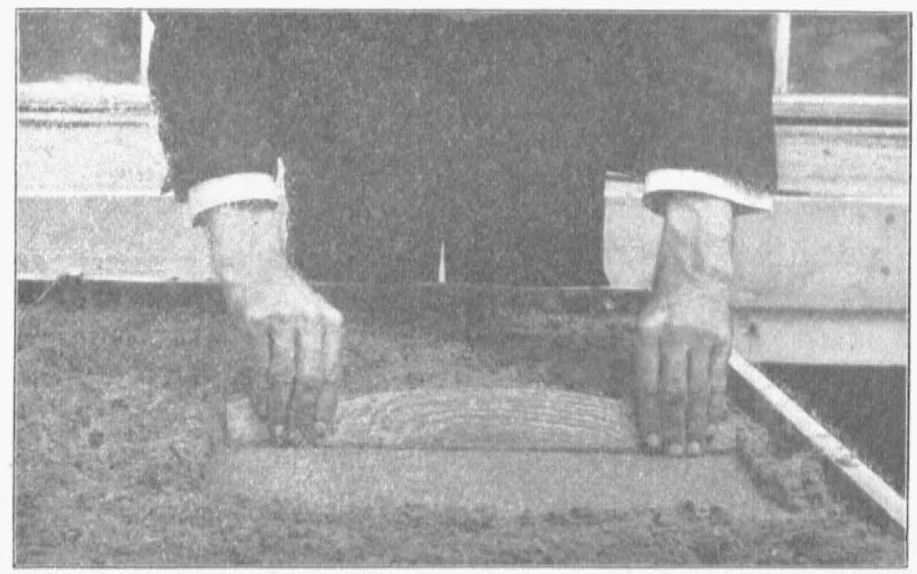

Fig. 6.-Smoothing the sand in a cutting bed.

wrapped in a wet newspaper or damp cloth. The geranium is a very desirable plant for use in the school room as it is a thrifty grower, is easy to handle and has showy flowers.

Geranium cuttings could be rooted in the propagating bed at school, then potted and removed to the home to help make up a window box or to join a group of potted plants in the window. If convenient it would be best to secure a few vigorous, old geraniums growing in pots from which to secure slips in the school- 
room. With a sharp knife remove the branches from the old plant; cut the end of the stem off smoothly, remove the leaves for an inch or two, allowing one or two leaves to remain, and cut the stem off again, and the first cutting is made. See Fig. 5, $a$. The length of a geranium cutting will vary from two to three inches. The points to be observed are, that at least an inch of the cutting should be buried in the sand and one or two leaves be left above ground. It is a general rule in making all cuttings to sever the stem at the

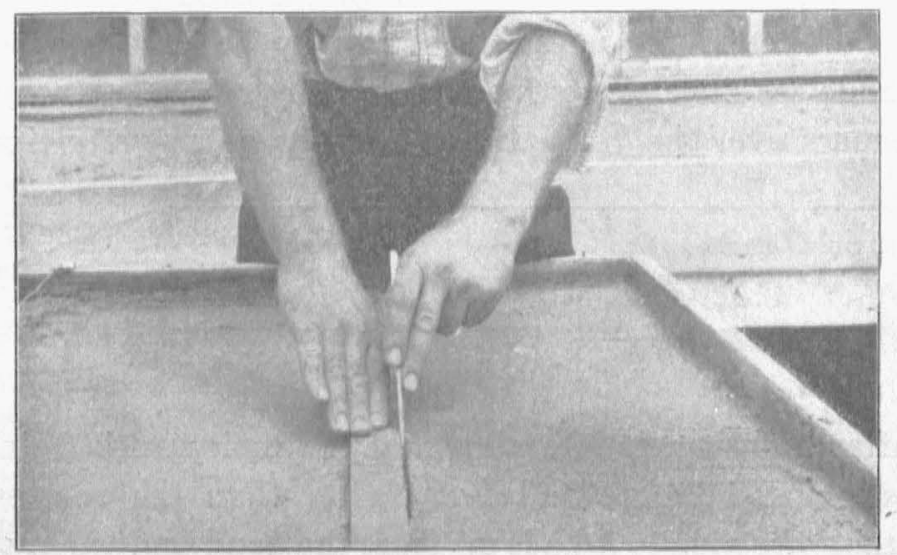

Fig. 7.-Marking off rows in the cutting bed.

lower end just below a bud. The last cutting made from a stem will contain the terminal bud and a number of leaves growing close together. Trim off all these but two or three, as in Fig. 5, $b$. In all cases, with all plants, if the leaves are large, they should be partially cut away as shown in the last figure, in order that they may not evaporate too much moisture from the cutting before the roots form.

Sprinkle the cutting bed well and level with a 
board, as shown in Fig. 6. Lay the board flat down and mark off rows three inches apart, the mark consisting of a cut in the sand with a piece of shingle. See Fig. 7. Place the cuttings in this little furrow and press the sand up snugly and firmly against them. Each different kind of plant should have a separate label giving its name, the name of the person to whom it belongs, and the date of planting. Fig. 8 is a common form of label. It is four inches long and made of soft pine. Labels like this may be secured from the large seed houses for about fifty cents per thousand.

After planting all cuttings in the sand bed, sprinkle well and for a few days it may be necessary to shade the little plants from the sun by spreading newspapers over the bed. If the cuttings wilt at any time

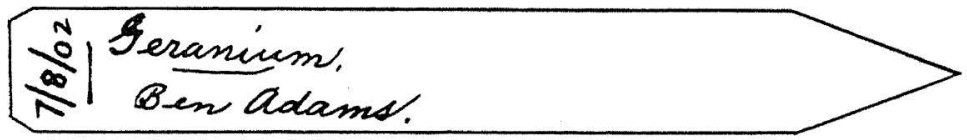

Fig. 8.-A cutting or pot label.

after planting, it is a sign that the moisture is being evaporated from the leaves faster than the rootless stems are able to take it up from the sand and we must come to the rescue by providing a shade. Geraniums should form roots in from ten to fourteen days. If they can have bottom heat-that is, where the sand can be kept warmer than the air above-as in a propagating oven or hotbed, they will begin to root in four or five days. When they have formed roots they should be transferred to pots, planting them in soil. Two-inch pots may be bought from pottery companies or dealers in florists' supplies, for about three dollars per thousand. After the plants have begun to grow in the soil and the roots begin to be crowded in the 
small pots, they may be transferred to larger receptacles such as old tin cans and the like. Geraniums should not be set out of doors before May. Geraniums are never propagated by seeds except by experimenters who are trying to produce new varieties.

Roses are commonly propagated from cuttings of firm or nearly mature wood with a mild bottom heat of sixty-five or seventy degrees. They are generally made in February or March from growing plants. The exact way to make a rose cutting will be seen by reference to Fig. 9, a. Three buds are on the section of stem, the piece being cut off just below one of them. Only one leaf is left on each cutting and it should be noted that the upper end is cut off some distance above the attachment of the leaf. This prevents the upper bud from drying out and being injured. Rose cuttings are rather slow to root without bottom heat, usually requiring about three weeks for the process. Before the roots can form the wound at the end of the stem must heal, which forms a growth called a callous. After callousing the little roots soon begin to show: Occasionally roses are propagated from layers in summer, or by budding or grafting.

Begonias root readily from cuttings but do best with a bottom heat of $70^{\circ} \mathrm{F}$. The lower end of a cutting should always be cut off just below a joint. There are a large number of begonias, some being grown principally for their ornamental foliage, while others have very handsome flowers. In Fig. $9, b$ is seen a properly made stem cutting of a begonia. Portions of the two remaining leaves have been clipped off.

The well known rex begonia is propagated from its leaves. Select old, well matured leaves, and make a little cut with a sharp knife across the principal 
nerves on the under side. They should be placed on the sand and held down by means of splinters thrust through them and into the sand, or weighted down with little pebbles laid upon them. At the cut places on the nerves enlargements of the parts will take place and roots will form on the lower side while the little plants will spring up above. Another way is to divide the leaf into two nearly equal parts, lengthwise, and set

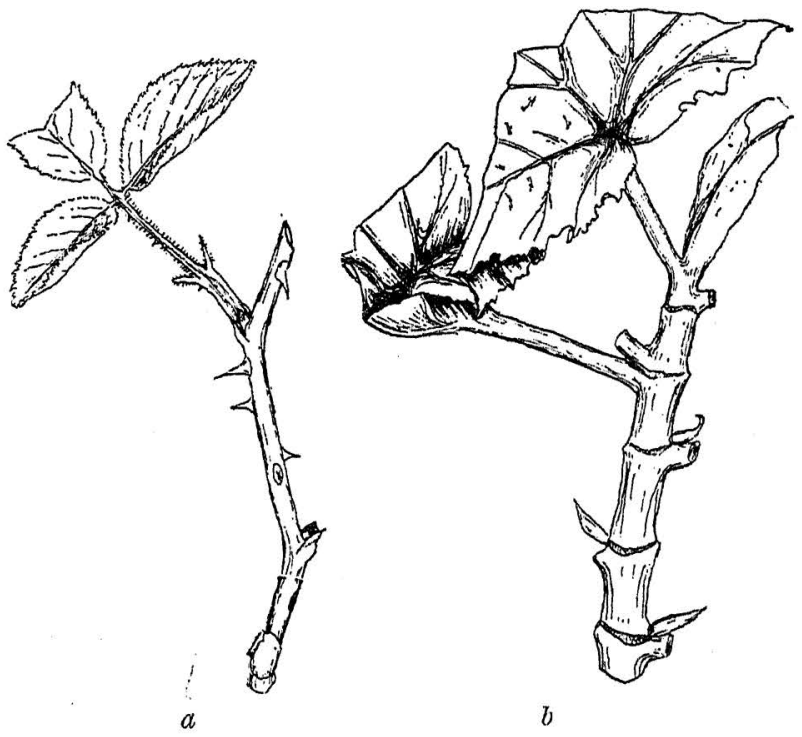

Fig. 9.-(a) A rose cutting; (b) a begonia cutting.

each piece upright with the cut edge buried in the sand. See Fig. 10, $a$ and $b$. Fewer plants are obtained in this way-often only one-but they are strong. By either method, when two or three leaves have formed, it is time to transfer the young plants to pots.

Begonias require a light, sandy soil, and plenty of moisture. A soil made up nearly entirely of leaf mould is the best mixture for them to grow in. They 
will not tolerate a heavy clay soil. If the soil they are planted in holds water they will die. Begonias are easy to grow in pots in the house if the above precautions are observed, but if carelessly handled will be very unsatisfactory. Small plants are much more difficult to manage than large ones. After becoming one or two years old they are not hard to keep.

In Fig. 11, $a$ is shown a hydrangea cutting ready for planting in the propagating bed. With this plant the leaves are so large that even though only two are left on the cutting it is necessary to clip off a portion of them. The hydrangea makes a handsome pot plant

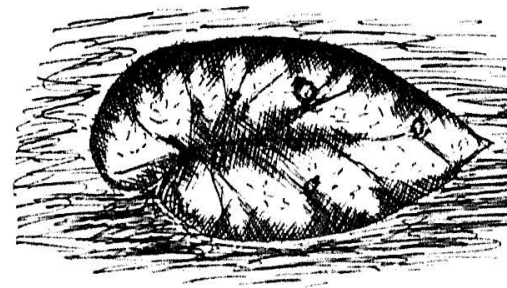

$a$

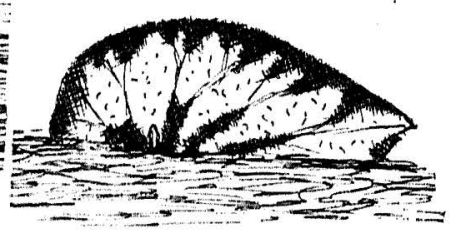

()

Fig. 10.-(a) A begonia whole leaf cutting; $(b)$ a begonia half leaf cutting.

for the home in winter and may be transplanted to a shrubbery border to remain through the summer and early autumn. If it is not convenient to keep this plant in the house during the winter, it may be left outside until the leaves have fallen when it may be taken up with a ball of earth about the roots and stored in a dry cellar where it does not freeze. In spring plant out again. The above applies to Hydrangea hortensis and its varieties, but there is another form-the paniculata-which is entirely hardy and may be planted permanently in the yard. The paniculata is propagated by cuttings and by layers. 
The heliotrope is one of the oldest, best known and highly prized flowers. The flowers are not so handsome as many others but their sweet perfume is unsurpassed. From old potted plants cuttings may be made in late winter, or early spring, and rooted in sand. See Fig. 11, $b$. When warm weather comes they can be set in flower beds or left to grow in pots. There are both purple and white flowered varities.

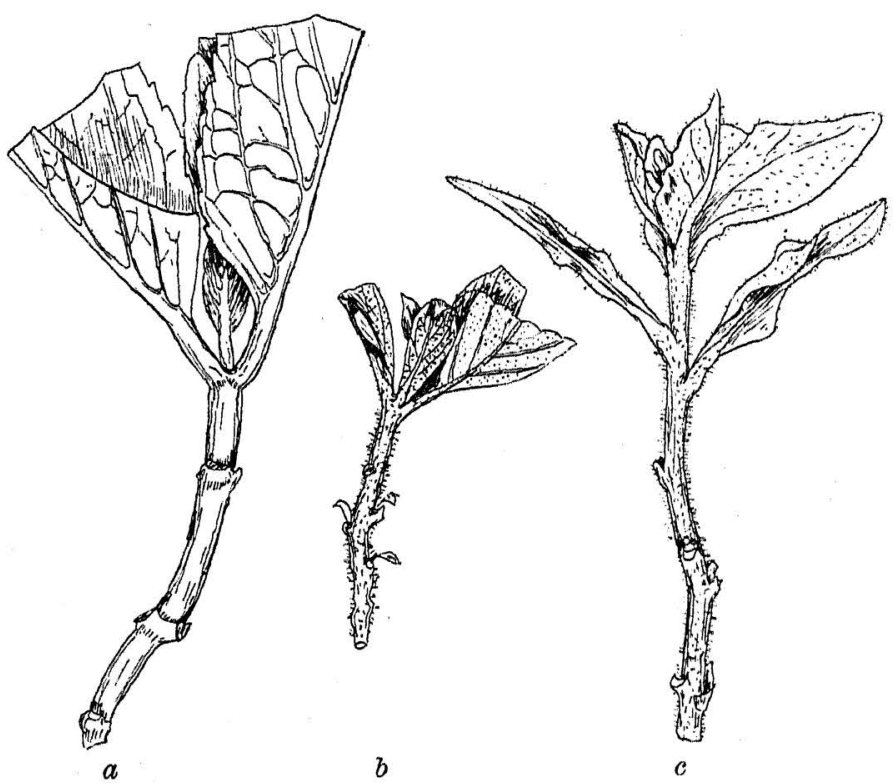

Fig. 11.-(a) A hydrangea cutting; $(b)$ a heliotrope cutting; (c) a cutting of double petunia.

Petunias are of two sorts - the single and double flowered. The former are reproduced from seeds but the double-flowering kinds are propagated from cuttings. There are many varities of double petunias presenting a diversity of colors and a combination of shades. They are really very pretty flowers and are much admired. Old plants may be kept in pots all 
winter and kept growing. Cuttings may be made at most any time but preferably in early spring. The younger stems are best for this purpose. Fig. 11, $c$ shows a cutting ready for planting in the sand. Pot off when rooted and in summer plant in beds.

Chrysanthemums are favorite flowers in season and are easily grown from cuttings. It would not be so easy to produce the large, handsome flowers for Christmas times, but there is no reason why every family and school should not have some good pot specimens to set in a window for early spring blooming. Fig. 12, $a$, shows a properly made cutting with a portion of the large leaves cut off. Make cuttings in early spring and pot off when rooted. Repot as often as the roots become crowded and in summer plant in the garden. Transplant back to pots in August and after they are established if care is exercised to keep them in a cool room and water just enough to keep them alive until about December, and then watered as much as they can bear, Christmas flowers can be had. However, it requires some skill in handling to hold back for the holiday flowering, and it is much easier to keep them growing after removing from the garden and let them flower during the autumn. After flowering, cut back the old stalks to near the ground. In a short time new shoots will spring up and if properly cared for these will flower in early spring. Chrysanthemums require a rather low temperature, $40^{\circ}$ to $50^{\circ} \mathrm{F}$., all of the time they are in the house. They would die in a temperature where roses would thrive. Sweet alyssum is easily grown from cuttings like Fig. 12, $b$. It is a low plant with small white flowers having a delicately sweet odor. 'Very desirable as a cut flower in winter time when blossoms of all kinds 
are scarce. Alyssum is an excellent border plant for a window box, drooping over the side in a very pretty manner. It may also be used in hanging baskets. Does not require any special attention either in summer or winter.

Coleus, with its variegated and many colored foliage, is a very popular plant and probably always will be. Coleus is grown almost wholly for the foli-

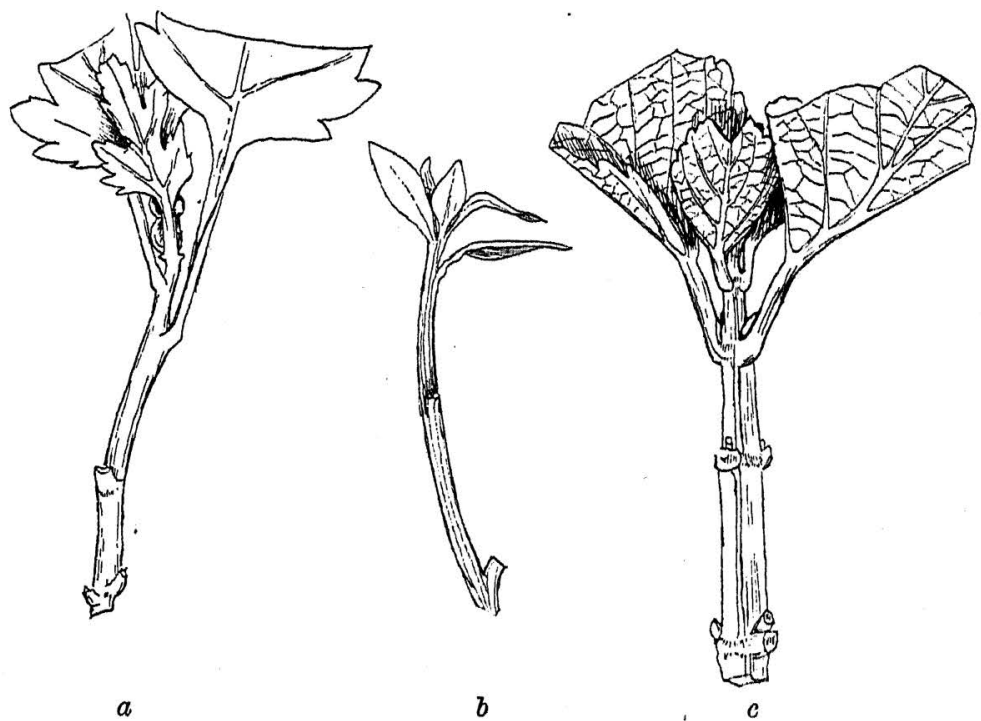

Fig. 12.-Cuttings of (a) chrysanthemum; (b) sweet alyssum; (c) coleus.

age, for as a rule the flowers are inconspicuous. It is one of the easiest plants of all to propagate from cuttings. Fig. 12, c, shows how to make the cuttings. This one contains a terminal bud. If more than one are to be made from a single stem they would be made as this one is, but with the stem cut off at the first joint above where the leaves are attached. Coleus is largely used in beds where the plants are to form some special design, as a star, or letters of a word, 
such as is often seen in a flower garden about railway stations and public parks. The plant is a rapid grower and will bear being sheared and trimmed in a manner that would kill many other plants. The most common color of leaves is a greenish-yellow, turning to a decided yellow in late summer if grown in full sunlight. Others, of very dark red, almost bronze, and gaily variegated shades and colors are also quite common.

A variety of coleus having ornamental flowers has recently been originated.

Fuchsias grow well in certain locations, and their

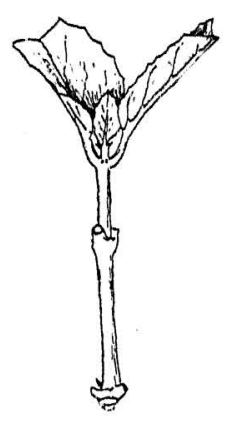

a

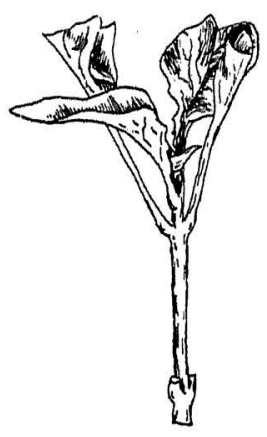

$b$

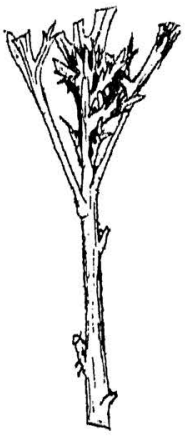

c

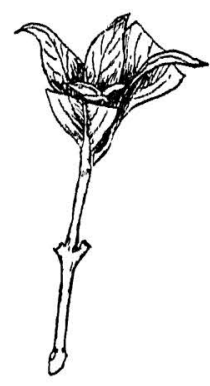

$d$

Fig. 13.-Cuttings of (a) fuchsia; (b) alternanthera; (c) marguerite; (d) cigar plant.

wax-like odd-looking flowers are much admired. Cuttings like Fig. 13, a, readily take root. The plants may easily be grown in summer in shaded places.

Alternanthera is chiefly used as a border plant. If kept sheared properly it makes a dense, attractive little hedge about four inches high. The flowers are scarcely noticible. The leaves are green, dark red and variegated. See Fig. 13, b, for prepared cutting of natural size. It thrives best in sunny locations but will grow in partial shade. 
The marguerite makes a desirable plant for either summer or winter and may be readily grown from cuttings. See Fig. 13, c. The marguerite, which is sometimes called the Paris daisy, makes acceptable cut flowers at any season. Set the little plants in the garden in May and in early autumn, before any danger of frost, dig up with a ball of earth attached to the roots, and transplant to pots. They may be kept in

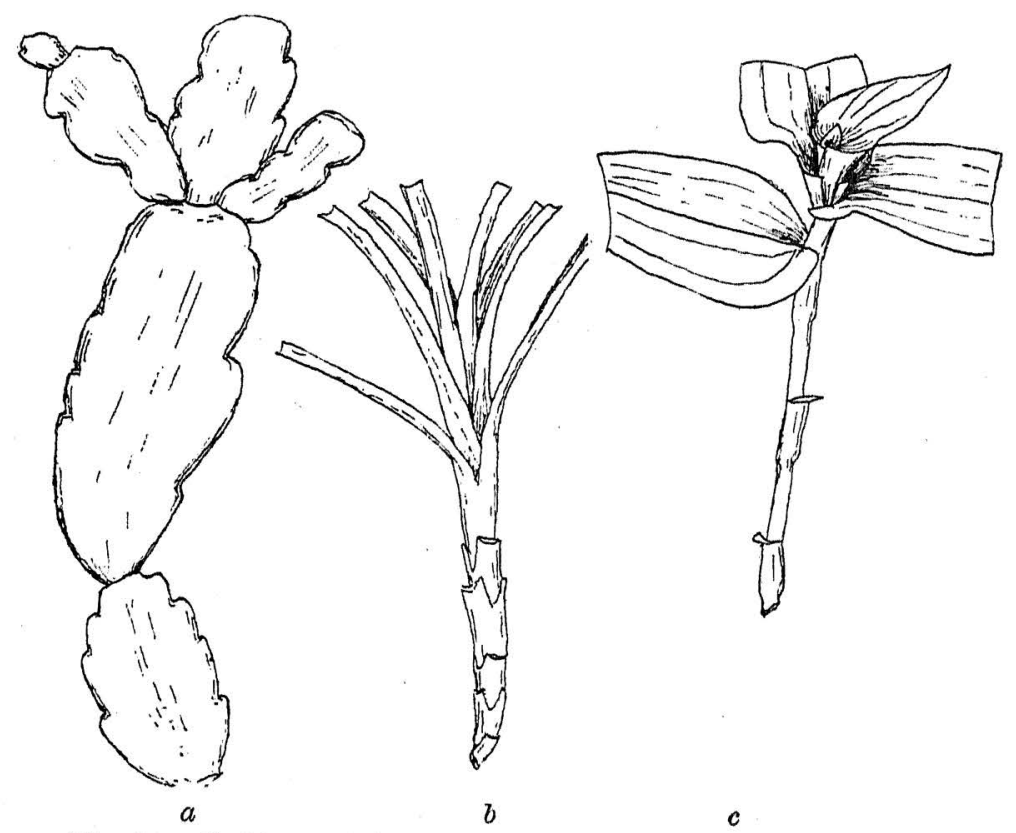

Fig. 14.-Cuttings of (a) crab-cactus; (b) carnation; (c) wandering Jew.

pots all winter and set out in the garden again the following spring.

The cuphea or cigar plant is an attractive thing, with its long, cigar-shaped red flowers. Cuttings like. that shown in Fig. 13, $d$, strike root readily and quickly in moist sand and may be planted in the flower bed in late spring. The cigar plant seldom grows 
more than a foot high but has somewhat of a spreading habit. Being rather low it is best used near the border of the flower bed where it is in plain view.

Fig. 14, $a$, is to show how a cactus plant may be propagated from a cutting. This one is a crab-cactus, but the night-blooming cereus may be grown in the same manner. Cactus cuttings do not require as much watering as the other plants described. After being potted or planted out of doors they still require but little water.

The carnation is liked by all and can be easily grown from cuttings. Cuttings made in the early spring may be rooted and planted out when warm weather comes, and will flower during the summer. Carnation culture in the house is attended with so many difficulties that disappointment usually results from its trial by amateurs. The plants may be taken up in the fall and set in pots or boxes and kept in a cool cellar-where the temperature does not go higher than $50^{\circ} \mathrm{F}$., nor lower than $30^{\circ} \mathrm{F}$--over winter and thus have strong plants for spring planting. See Fig. $14, b$, for a carnation cutting.

Fig. 14, c, shows a cutting of a plant which will not require any pains to grow. It is the wandering Jew (Tradescantia). It roots in a few days in moist sand and can be grown almost anywhere. It is purely a foliage plant, the common form being green, but there are some very attractive variegated forms. Wandering Jew makes a good hanging basket and serves a like purpose when set in a window box, where it can hang over the edge. It naturally prefers a moist place to live, but will grow under the most discouraging circumstances.

Grape cuttings.-All of our cultivated grapes are 
propagated almost entirely from hard-wood cuttings, either as three-eye cuttings to be rooted in the field. or as single-eye cuttings, generally to be rooted in a sand bed. Grape cuttings may be made at any time during the winter or very early spring before the buds begin to swell. However, it is best to make them early in the winter before severely cold weather begins as the wood is sometimes injured by freezing to such an extent that cuttings made from it will not root. The cuttings are prepared from the wood of last season's. growth. For instance, if the cuttings are to be made in December of 1902, they should be from the wood which grew during the summer of 1902 . Select a suitable vine and begin at the point where it was cut from the mother vine. First cut the vine off smoothly just below a joint (node) where there is a bud. Counting this bud one, count upward to the fourth bud and cut off again below the joint, which leaves three buds on the completed cutting. See Fig. 15, a. Continue in a like manner until the vine is all used. Tie the cuttings. in bundles of about fifty each and pack them away in a box of fresh, green sawdust from a sawmill where green logs are being sawed. It is best to store the cuttings in a cellar where they will not freeze.

In spring at gardening time the cuttings are to be planted in the nursery. Prepare the soil by plowing it deeply and then smoothing with a harrow and last with a roller.or drag. Have the rows at least forty inches apart, and the cuttings may be set three or four inches apart in the rows. To plant the cuttings, punch holes in the ground with a sharpened pole to a depth of seven or eight inches. Place the cuttings in the ground so that the upper bud will be just above the ground. With a short, sharp stick, or a dibble, press 
the soil all the way down to the bottom of the hole, closely and tightly about the cutting, as it will never take root if there are air spaces left about it.

Single-eye grape cuttings are made as shown in Fig. 15, $b$, from the same kind of material, etc., as in the other, but these are planted in sand in a propagating bed either as soon as cut from the vine or later. Place the single-eye cutting in the sand horizontally,
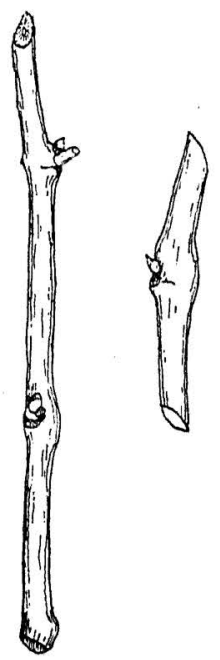

a

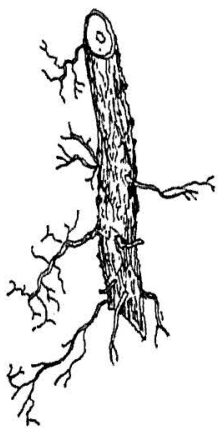

$c$

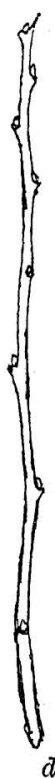

$d$

Fig. 15.-(a) A three-eye hard-wood grape cutting; (b) a singleeye grape cutting; (c) blackberrv root cutting; (d) cutting of Marianna plum.

with the bud upward, and the whole covered with sand. Pot off when rooted and plant out in the spring. This method, as well as the use of green cuttings of grapevines in summer, are resorted to when wood is scarce or when it is necessary to multiply the vines rapidly, but they are thought to make weaker plants than the three-eye cuttings. 
Blackberry plants are propagated from sprouts and from root cuttings. The latter are made as shown in Fig. 15, $d$, of a section of root two or three inches long and from one-quarter to three-eighths of an inch thick. They may be prepared in the winter and packed in moist sand or green sawdust until spring, or immediately started in a propagating bed and potted until time to set them out in spring. In sand beds they should be laid horizontally and covered about two inches deep. The root cuttings may also be prepared in spring and sowed in a furrow like peas.

One type of plum, the Marianna, roots readily from hard-wood cuttings. The cuttings are made about six inches long and from wood of last season's growth. See Fig. 15, $d$. They should be tied in bundles and packed in green sawdust until spring when they are to be planted in the nursery. The best plan for planting is to make a furrow in well prepared soil, with a six-inch turning plow, place the cuttings in the furrow against the vertical wall and draw the earth up against them, tramping firmly and leaving two or three buds above the ground.

The Marianna plum is of no value as a producer of fruit but the rooted cuttings make excellent stocks upon which to bud desirable varieties.

\section{LAYERING.}

A layer is a branch, shoot or root of a plant partially covered with earth, with the intention that it shall grow and then be cut off from the parent plant. A great many plants may be multiplied by layering. 
The rose bush, for example, is increased by pulling down a branch in spring and covering it with earth at one or more places throughout its length. The buried places will take root if the season is favorable and late in the fall, or better, the following spring, may be severed from the parent plant. Grapevines which root with difficulty from cuttings, like Norton's Virginia variety, are often propagated in this way. Many of the ornamental shrubs are layered in spring or summer. Almost all of the common cultivated woody plants may be rooted by layering if the season is not too dry.

A special form of layering employed in the propagation of some plants like currants and gooseberries, is to bank the soil up around the clump of plants in the spring and when rooted the earth may be raked away and the plants cut off at the surface of the ground. This is called mound layering.

Another special method of multiplication which may be classed under the head of layering, is the way some of the greenhouse plants, like the rubber plant (Ficus elastica), which are difficult to root from cuttings, are propagated. This consists of binding a handful of spagnum moss (a special kind of swamp moss used by florists for packing plants for shipment) around the stem of the plant and leaving it there until roots form at that point. The moss of course must be kept damp but that is not difficult as this material is very retentive of moisture, which makes it of great value for packing live plants for transportation. It will require many weeks for a rubber plant to root as described, but when it does it may be cut off below the rooted point and potted in the soil. 
Still another form of layering is that of blackcap raspberries which reproduce themselves from the tips of their long, drooping branches which touch the ground and take root. The red raspberries are reproduced from suckers which come up abundantly in the rows among the plants, and from root cuttings.

\section{GRAFTING.}

Grafting is the process of making a piece of one plant grow on another plant, usually spoken of as inserting a scion on a stock.

Grafting is the principal method of propagating apple trees, as this fruit does not come true from the seed. Occasionally apple trees are budded, but budding is chiefly confined to the peach and plum.

In describing how to propagate apple trees by grafting it is necessary to begin at the beginning - that is with the seeds. In the fall of the year we save the seeds from apples used about the house. If it is convenient to get apple pomace (the ground-up and squeezed-out refuse of apples) from some place where cider is being made, the seeds can be collected rapidly. Pour the pomace into a barrel two-thirds full of water, and stir the mass with a stick. The seeds will settle to the bottom as they are separated from the flesh of the apple and the coarser part of the pomace may be skimmed off. The fine particles of the pulp will settle down with the seeds and unless one has a wheat sieve at hand to help, it is a tedious matter to separate all the seeds from the pomace. It is more agreeable, of course, to have all of the seeds clear of the pomace, 
but it is not at all necessary. When the apples are being dried or canned it is a good job for the children to cut the seeds from the cores. A surprisingly large number of seeds may be secured in this way in a very short time. To get best results the seeds should not be allowed to dry out, but should be stored in sand for the winter. This is done by putting a layer of common sand in a box, spreading over it a layer of seeds, then more sand, and so on, until the seeds are all used up. Place this box on the north side of a building, sinking it in the earth until it is level with the top of the ground, in order to keep the sand moist. Do not cover the box but leave it exposed so that the rain may get in and help to keep the sand from drying out. This is called "stratifying" the seeds and it does not matter if there is some of the pomace left with them when they are planted in the sand.

The seeds are to remain stratified until they are ready to plant, which will be in spring at gardening time. Select a place where the soil is deep and fairly rich. It is very important that the soil be deep so that the roots can go straight down, for it is the roots that we are after, and the longer they can be made to grow, the better. Plow the land deeply and prepare as for garden truck. Lay off rows four feet apart and sow the seeds not too thickly in the rows. Instead of using soil it is a good idea to cover the seeds with thoroughly rotted chip dirt, straw or manure, but whatever is used should be free from weed seeds. Give the seeds only a shallow covering. Give the little seedlings good cultivation throughout the summer and keep them growing vigorously. Late in the fall after the leaves have been shed, the plants are to be dug up and stored in the cellar. Cut off all but four or five 
inches of the tops, tie the plants in bundles and pack them in green sawdust. Sand that is slightly moist may be used but it is not as good as sawdust.

The scions for grafting on the roots may be taken from the trees at any time after the leaves have fallen, but it is well to cut them before the first hard freeze. Never cut scions while they are frozen; if cold weather comes on suddenly, before the scions are taken, wait until they are thawed out. In the first place decide

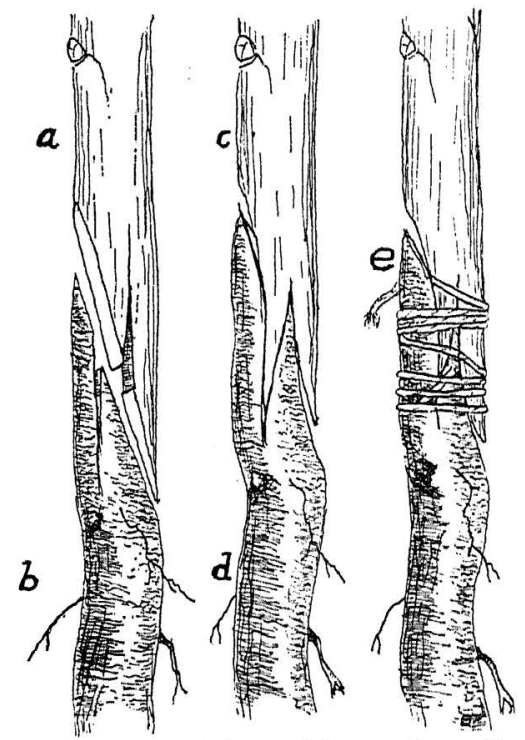

Fig. 16.-How to make a whip or "tongue" graft. (a) shows how to make the sloping cut, and the slit or "tongue" in the scion; (b) shows the corresponding sloping cut and "tongue" for the root; $(c)$ and $(d)$ illustrate the proper manner of uniting and tying the scion and the root, forming the finished graft.

what varieties are wanted, then go to a healthy tree that is known to produce good crops of the desired sort, and cut from it the best twigs of the last season's growth. Wood that is two years old is not suitable for grafting. Get the switches as long as possible, but they can be used if the growth has not been more than 
four or five inches. Water sprouts when they have sprung out well above the ground, may be used if they are well matured. Never use soft, spongy, immature wood, or any which has refused to shed its leaves. If the scions are taken from the tree early, they should be packed in green sawdust like the roots. Grafting may be done almost any time in January or February, or even March, in the northern half of the state, but February is perhaps the best time to do the work. The grafting should be done in a cellar or basement room, but may be done in a moderately warm living room. Do not work about an open fire or near a hot stove as the roots may be dried out and seriously injured.

Making the grafts.-If the twig's have made a sufficient growth, make the scions six or seven inches long, but they may be made shorter if necessary. On the butt end of the scion make a sloping cut about an inch to an inch and a half long, as shown in Fig. 16, a. Use a sharp knife and make the cut smooth and uniform. On the sloping surface about one-third of the way from the end of the twig, make a "tongue" by a downward cut from one-half to an inch deep, along the grain of the wood. With nurserymen it is customary to form the sloping cut, make the "tongue," and then cut off the scion of the desired length. Follow the same process with the root. Begin at the crown (the part of the root that was just at the surface of the ground), and form a sloping cut, taking care that it is of the same slope as that of the scion, and make the tongue in the same way and at the same distance from the end of the root as in the scion. See Fig. 16, $b$. This done, cut the root off, having the piece three or four inches long, and repeat the process until the root is all used. If the seedlings 
have made a good growth and the soil has been porous enough to let them go down, the roots will usually make two and sometimes three pieces.

Join the root and scion by pressing the two sloping surfaces together and forcing the tongues to interlock. At this point, the main thing to be observed is, to see that the bark line of the scion comes exactly in contact with the bark line on the root. This is highly important, for this is where the two are to grow together. The scion and root may not be of the same thickness-in fact, seldom are, but this makes no difference if the above instructions are followed.

Figure 16, $c$ and $d$, shows the scion and root properly united. After pressing the two pieces together it will be necessary to wrap the graft with No. 18 or 20 cotton knitting thread. Lay the thread on the wood near the end of the cut, wind two or three rounds on top of it, at the same time pressing the scion and root together with thumb and finger; then work the thread up to the other end of the cut by winding it two or three times around the graft during the distance, then two or three times around the other end of the cut as in the beginning, and fasten the end of the thread by drawing it down in the cut, and, by a sharp jerk, break it off as shown at $e$, in Fig. 16. This completes the graft, as it is not at all necessary to wax the union. This process is known as "whip-grafting." Pack the grafts in bundles, each bundle being tied up, in green sawdust, where they are to remain until planting time. The wound at the point of union will actually begin to heal over and partially grow together while the grafts are in the sawdust, and on this account they should not be disturbed until they are taken out to plant. Keep the box of grafts in a cellar or moderately cool 
room. They must not be allowed to freeze, neither must they be allowed to dry out.

Planting.-As soon as the ground will do to work in the spring, select a place where the soil is moderately rich, on which to plant the grafts. Do not plant them on the site of an old strawstack as that is entirely too rich. Plow the land deeply and otherwise prepare as for a garden spot. The rows need not be long but should be perfectly straight. To get them straight, stretch a line or wire across the plot. The
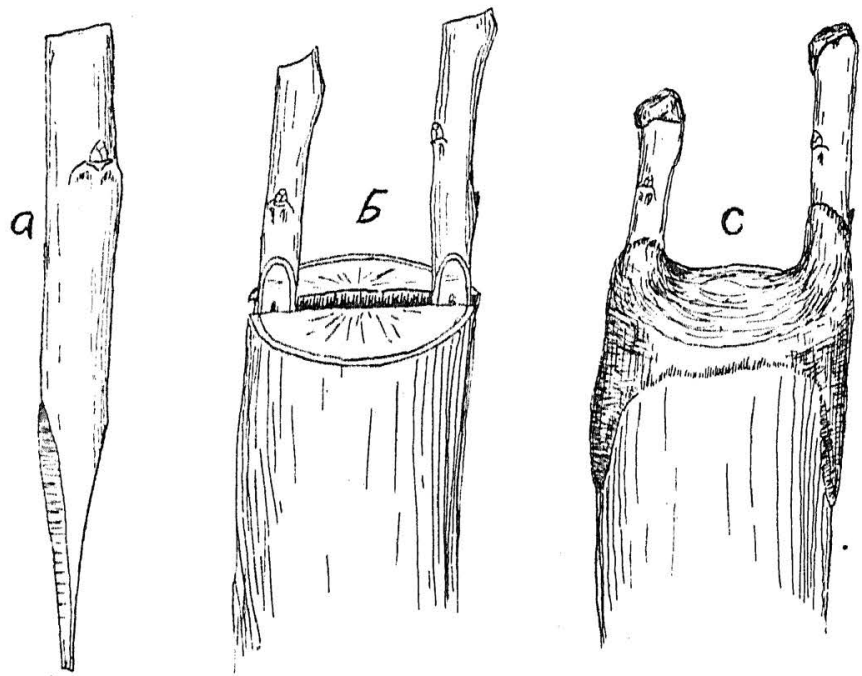

Fig. 17.- How to make a "cleft" or "top-graft;" (a) the scion whittled to a wedge-shape; (b) a sawed off trunk or branch, with two scions correctly inserted in the split end; (c) the branch covered over with grafting wax.

rows are to be four feet apart but are not to be laid off with a plow. After lining up the rows go along with a sharpened pole and punch holes in the ground along that line, about eight inches apart, withdrawing the pole carefully so as to not let the soil tumble in. Plant the grafts by placing them down in these holes so that one or two buds of the scion will be above 
ground. This will necessitate the ground being plowed deeply. Be sure to press the soil up closely against the roots of the grafts; this is best done with a dibble or short stick which is forced into the ground beside the grafts and crowds the soil up against them. The grafts can not grow if air spaces are left around the roots. Here is where more people fail than at any other point. Give the little trees good culture, including two or three hoeings, during the summer, and with a reasonably fair season, they will reward their owner with a vigorous growth.

Cleft-grafting.-There is another form of grafting often of use to any one having even a few fruit trees, that will be considered briefly. This is what is known as "cleft-grafting." If an apple tree reaches bearing age and is found to be an undesirable variety, the kind that is wanted may be worked on the tree by this method of grafting. The method is also sometimes called "top-grafting." As many varieties as there are branches to put them on may be top-grafted upon a single tree. New varieties may be hurried into bearing by being worked on the branches of an old tree.

To do the grafting, saw off the old branch, or even the body of the tree if it is not more than four inches thick, and split the stump down through the center with a knife or hatchet. This work is to be done in spring just as the buds are beginning to swell, but the scions to be used must have been collected some time previous when the wood was perfectly dormant. The scion should be four or five inches long and at the butt end whittled to a wedge-shape, as shown in Fig. 17, a. In making the wedge the slope must be long and uniform, the wood being whittled from both sides of the 
scion. Pry open the split in the trunk or branch to be grafted, and carefully insert the scion so that its bark will be exactly in contact with the inner growing bark of the old stub or stump. See Fig. 17, $b$. This is very important, for here is the place where they are to grow together, and they can not do so unless the bark of one piece is in line with the bark of the other. If the old branch or trunk of the tree is large enough-that is, thick enough, it is advisable to use two scions, as this will double the chances of success, in case one of them does not grow. If both scions grow, by all means cut one of them out. If both of them are allowed to stand a forked tree will be formed, which is always to be avoided. When the scions are in place it will be necessary to cover over all the cut surfaces with grafting wax. See Fig. 17, c. The wax may be melted in a tin can at the house and carried to the orchard, if not too far away. It is best to have a little paddle with which to dip up the molten wax and spread it over and around the scion in such a manner as to exclude the air and thus keep them from drying out until they unite with the old wood. This wax is never to be disturbed afterwards as it will not injure the tree.

To make grafting wax.-Common rosin, 7 lbs., beeswax, $2 \mathrm{lbs}$, and tallow, $1 \mathrm{lb}$. If so much is not desired, divide each of the above items by 2,3 or 4 , as may be needed. Melt all of the ingredients together over a slow fire, and stir thoroughly. When well mixed, pour a part of the mass in a small tub of water until partially cooled, then take it out and pull like taffy candy until it becomes too stiff to work.

Pears.-To propagate pears, the seedlings may be grown and cared for like apples, but when it comes 
to grafting, the roots must be left whole and the place where the scion and root are united covered entirely with grafting wax. Plant and cultivate like apple grafts.

\section{BUDDING.}

Budding is the operation of removing a bud from one plant and inserting it on some other plant with the intention that it shall grow.

Peaches, plums and cherries are propagated almost entirely by budding, the work usually being done in summer or early fall. The process-including the growing of the stock-is practically the same for all of the above named fruits, so that a description for peaches will answer for the whole. Plum stock is also secured by rooting cuttings of the Marianna plum.

Peach seeds may be planted in the fall, or stratified during the winter as described for apple seeds, and planted in the spring. They should not be allowed to lie in the sun and dry out during late summer and fall. The seedlings will make a vigorous growth with a reasonably favorable season and may be budded in August or early September. In general the budding should be done when the bark peels best.

The buds are to be selected from the desired varieties when the work is ready to be done. Take a young branch that has been growing during the current season and cut away the part of it which is soft and immature. The best wood buds (the kind to be used) are found toward the middle of the twig. Fig. 18, a, where the leaves are cut away, shows in a general way where the desirable buds are to be found. 
The wood buds may be distinguished from the fruit buds by remembering that they are smaller, flatter and never so plump. A fruit bud can do no particular harm if there is also a wood bud. The wood bud is what makes the wood growth that we desire, while a fruit bud will simply bloom out and die, and that is the end of it. A wood bud will often have a fruit bud on each side of it, but that does not matter. When this occurs the outside buds may be broken off as they are of no use. After a little observation and practice it will be easy to select the proper kind of buds.

The weather is usually very warm at budding time so that it will be necessary to wrap the sticks from which the buds are to be taken, in a damp cloth or heavy piece of paper to prevent their drying out. Trim off the leaves, leaving a piece of stem about half an inch long to hold to when the buds are being inserted. The manner of cutting the buds from the twig-known as a "budding stick"--is shown in Fig. 18, b. Hold the budding stick in the left hand, upside down, and with the other hand force the knife down through the bark and into the wood and make a slice down to the dotted line shown near the bottom of the blade. Now withdraw the knife and, at a point shown at the dotted line, make a cut crosswise just through the bark and no deeper. If the bark peels easily-and it should at budding time-the bud may now be lifted up and the bark will part from the wood very readily. We prefer to have no wood adhering to the buds.

The little seedling peach should be budded as near the ground as it is convenient to work, which will be two or three inches from the surface of the soil. The first thing is to make a slit in the bark, length-wise, and 
at the upper end of this slit a cross-cut, thus forming a T-shaped figure on the bark of the sprout, illustrated in Fig. 18, c. The bark should peel readily, and in Fig. 18, $d$, may be seen how it has been gently raised with the point of the knife, and the flaps slightly
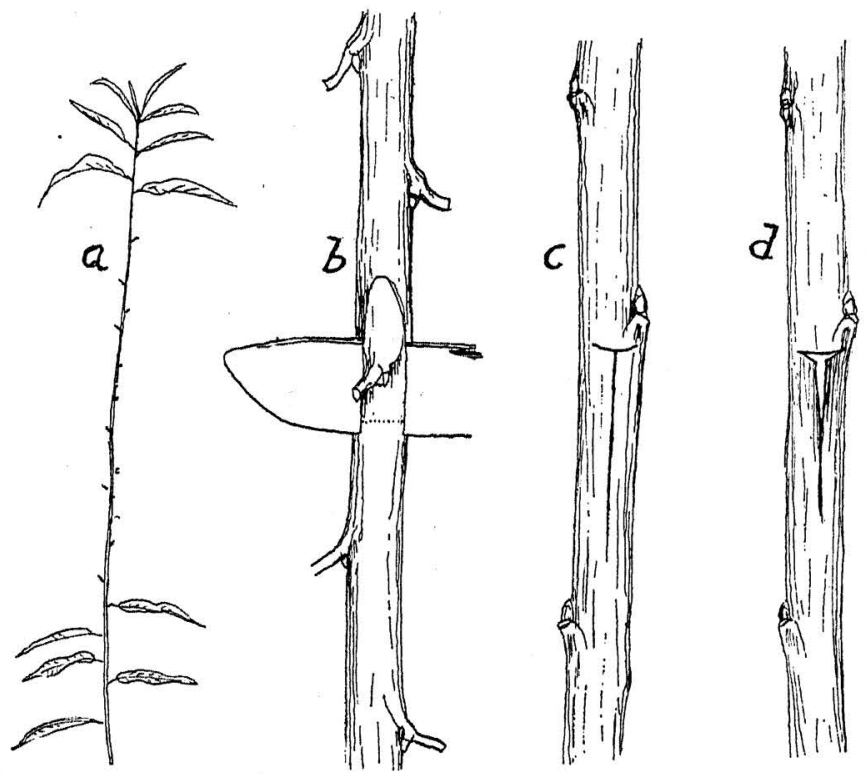

Fig. 18.-(a) A peach branch from which to secure buds; (b) method of removing a bud from a "budding stick;" (c) a T-shaped cut made in the bark of the seedling or other tree to be budded; $(d)$ the same with the bark partially raised for the insertion of the bud.

rolled back. At this point the buds should be cut from the budding stick, as directed, and inserted beneath. the bark of the sprout by holding to the short stem left for the purpose, and forcing it gently downward, sharp end first, until the square end of the bud gets down to where it will fit against the cross-cut in the bark of the stock. In Fig. 19, a, the bud is seen in position and ready for wrapping. In order that the bud may form a union with the growing bark of the stock, it is necessary to press it closely against the tree by binding 
with some sort of a string. Nurseryman usually use a kind of grass called "raffia," which is wet before applying and adjusts itself to the parts to be covered, and makes an excellent wrapper. A good substitute for "raffia," within the reach of every one, is strips of some kind of old thin, cotton goods. Whatever is used is to be bound around the newly inserted bud as indicated in Fig. 19, $b$, in such a manner as to leave

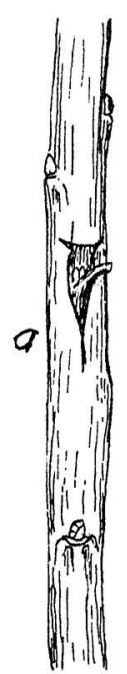

Fig. 19.-(a) The bud in place; (b) the inserted bud properly wrapped with a piece of raffia grass or strip of cotton cloth; $(c)$ where to cut the seedling off next spring after budding.

only the stem of the leaf left on the bud, sticking out. This leaf stem will serve as an index to show whether the bud has united or not. If the stem remains green, we may know that the bud is living, otherwise it will turn brown in a day or two. Do not wait longer than a week or ten days before examining the buds to see if they are living. If they have united with the trees, release the string by cutting it on the opposite side from the bud, in order not to disturb the healing 
wound. This early examination and cutting of the string must not be forgotten as it is very important. At this time the little trees are making a very rapid growth in thickness, and in a remarkably short time will grow over the strings and literally choke the trees to death, or, what is more to the point, will make a deep ring in the tree and cause it to break off where the bud is inserted.

During the season the bud is inserted on the tree, it will do no more than make a firm union with the stock, the bud itself remaining dormant. The follow. ing spring the bud will begin to grow along with the other buds on the tree, and now the little tree must be cut off from one half to an inch above the bud. See Fig. 19, c. This will throw all of the growth into the new bud and it will shoot upward rapidly. A large number of little sprouts will be certain to spring up around the stump and it will be necessary to rub them off about twice during the summer so as to keep the growth where it is wanted.

Planting peach trees. After the buds that we have inserted have made one seasons growth, the trees are ready to be planted in the orchard. In average soil, peach trees may be planted a rod apart each way, which gives 160 trees to the acre. At the time of planting, which should always be in spring, prune the peach by cutting all the branches back to stubs an inch or so long, thus leaving one or two buds to each stub. See Fig. 20, $a$ and $b$, for the tree before and after: pruning for planting. The top should be cut back into the firm wood. The roots may be cut back to a length of six inches and the tree is ready for planting:

Varieties. A few good varieties of peaches for a home orchard are: Elberta, Champion, Crosby, Old 
Mixon, Pickette's Late and Salway, which ripen in about the order named. This is by no means all of the good ones, but includes some of the leading sorts. For clingstones, Old Mixon Cling and Heath Cling are the best. Elberta, Champion and Crosby are the most successful market varieties. Others may be added at the pleasure of the planter.

Planting Apple trees. Apple trees may be planted in the orchard when one year old from the

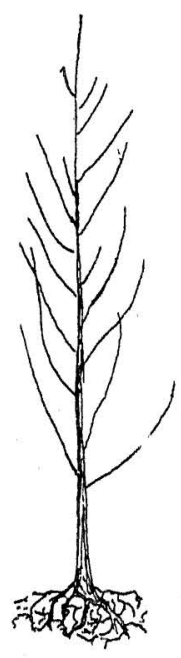

$a$

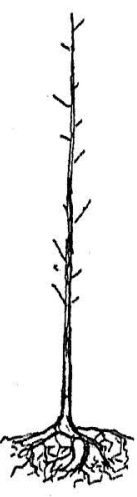

$b$

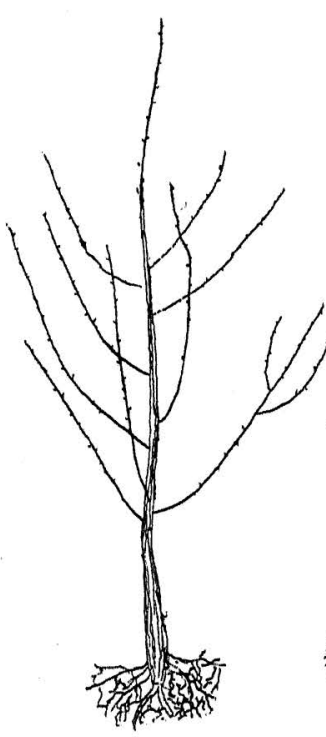

$c$

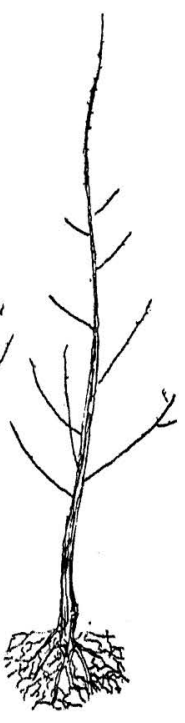

d

Fig. 20.- (a) Peach tree one year old from budding; $(b)$ the same ready for setting; (c) two year-old apple tree; (d) the same pruned ready for setting.

graft, but most people prefer to have them two years old. When planting, prune the trees to a cone shapethat is, leaving the lower branches longest and gradually tapering towards the top, and leaving the central stem as a leader, untouched, to continue the upward growth. See Fig. 20, $c$ and $d$. Prune the roots 
the same as the peach and plant in rows 25 to 30 feet apart each way. Where the soil is thin and the trees are not apt to make a vigorous growth, 25 feet apart is sufficient. Give the trees clean culture or sow to cow peas. Do not seed the orchard to either clover or timothy. At the time of planting, wrap the trees with wooden wrappers - a special kind of thin shingle made for this purpose, and sold by all box and basket companies, to protect the trees from the hot sun, to prevent borers from getting in and in winter to protect them from rabbits. Put the wrappers on loosely, so that the trees can continue to grow, and let them stay there until they rot off, going through the orchard each spring and sticking them down in the ground again, where the ends have decayed.

Varieties to plant depend on what they are wanted for; if for commercial purposes, that is, to place on the market in large quantities, then Ben Davis, Gano, Jonathan, York, and Grimes Golden would probably be the best short list for all localities in Missouri. A home orchard should include the above, and in addition, some early summer varieties so as to have a succession of fruit. Red June, Keswick Codlin, Early Harvest, Maiden Blush, Lowell, Rambo, Rome Beauty and Winesap are desirable varieties for early and late summer use.

\section{INSECTS AND FUNGOUS DISEASES.}

The principal insects of the apple which we are concerned with, are the borers, codling moth and canker worm. For borers, use wooden wrappers as directed; for the codling moth, do not use trap lanterns, 
for they are humbugs but fight the insect by spraying early in the season with Paris green at the rate of one pound to 175 gallons of water, also adding three pounds of fresh lime. Spray first a week after the flowers fall, then make three more applications at intervals of about ten days. Keep canker worms out of the trees by placing bands of cotton around the trunks; if they get on the trees, spray with Paris green when they appear, using the same amount of the poison as for the codling moth.

The most important fungus diseases are the scab and bitter rot. For these, spray with Bordeaux mixture, which consists of 4 pounds of bluestone (also called copper sulphate or blue vitriol) and 4 pounds of fresh lime, to fifty gallons of water. Spray the first time as the buds are swelling, again after the flowers have fallen, and twice more at intervals of two weeks. If bitter rot appears later in the summer, begin spraying again, giving two or three applications, at intervals of eight or ten days. Keep the orchard. clean and diseases will not be so likely to appear.

\section{GROWING VEGETABLES.}

Some useful lessons in vegetable growing may be given in the school room. In the propagating bed seeds of all the common garden vegetables may be planted and notes kept on the number of days required for the germination of each. Experiments may be made by planting the seeds at different depths and watching the effect on germination. If a little nitrate 
of soda can be secured it would be very instructive to apply a small quantity to some of the growing plants -like spinach or corn-growing in a pot, keeping another pot with the same kind of plant growing in it for comparison. Nitrate of soda contains a large per cent. of the element nitrogen, the constituent of the soil which causes the plants to make a vigorous growth and causes their leaves to take on a healthy, dark green color. Barnyard manure is rich in nitrogen. Clover, cow peas and common garden peas, all of which belong to a large family of plants, called by botanists, legumes, may be planted in the bed or in pots of soil. After the plants have formed good root systems dig them up and note that on many of the roots there are little knots or nodules. These are the work of certain minute organisms which have assisted the plant to take up from the air some of the nitrogen which occurs there in the form of a gas, and change it into such a form that it is available to all vegetation as plant food. When clover, cow peas or any of the leguminous plants are grown in a field, all of the nodules on the roots referred to are left to decay in the soil and consequently make it rich in one of the most important elements of plant food and one of the most expensive when it is necessary to apply it to the fields in the form of commercial fertilizer.

A hotbed which was described on page 11 is a very useful assistant in the growing of vegetables for the table use. Especially is it useful and necessary in the growing of certain garden plants out of their natural season. In the vegetable planting table given below the hotbed is often mentioned in connection with the growth of many of the plants given in the list.

By a cold frame is meant a device like a hotbed, 
but having no bottom heat nor any other heat except what may be furnished by the sun shining on the glass cover. In severe winter weather cold frames should have an extra wooden cover laid over the sash.

It being impracticable to enter into the details of vegetable gardening in this Bulletin, the following condensed table is given which, if studied, will furnish much information.

PLANTING TABLE FOR GARDEN VEGETABLES.

\begin{tabular}{|c|c|c|c|c|c|c|c|c|c|c|c|c|}
\hline & 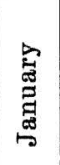 & 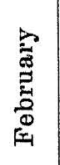 & 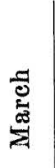 & $\frac{\bar{a}}{4}$ & 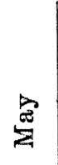 & $\stackrel{g}{\Xi}$ & $\stackrel{\vec{\Xi}}{\Xi}$ & $\begin{array}{l}\overrightarrow{0} \\
\stackrel{0}{0} \\
\stackrel{8}{\Xi}\end{array}$ & 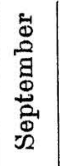 & $\begin{array}{l}0 \\
0 \\
0 \\
0 \\
0\end{array}$ & 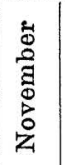 & 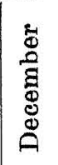 \\
\hline$n$ & & & 6 & & & & & & $\ldots$ & ${ }^{\circ}$ & $\cdots$ & \\
\hline & 7 & 7 & 7 & 1. & 3 & 3 & 3 & 1. & $\ldots$ & $\cdots$ & $\ldots$ & $\cdots$ \\
\hline$\cdots$ & $\cdots$ & $\cdots$ & & & 1 & 1 & & & $\cdots$ & $\cdots$ & $\ldots$ & \\
\hline & $\cdots$ & $\ldots$ & 5 & 5 & 1 & 1 & 1 & 1 & $\ldots$ & $\cdots$ & $\cdots$ & $\cdots$ \\
\hline 'ts & $\cdots$ & $=1$ & $\cdots$ & & & 2 & 2 & $\cdots$ & & & $\cdots \cdots$ & \\
\hline & 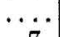 & 5 & 5 & 2 & 2 & 2 & & $\cdots$ & 8 & 8 & $\cdots$ &. \\
\hline . & 7 & 7 & 6 & 1 & 1 & 1. & 1 & $\cdots$ & $\cdots$ & $\cdots$ & $\cdots$ & \\
\hline & 7 & 7 & 4 & 2 & 2 & 2 & $\cdots$ & $\cdots$ & $\cdots$ & $\cdots$ & $\cdots \cdots$ & \\
\hline & $\cdots$ & 5 & 5 & 2 & 2 & 2 & $?$ & $\pi^{\circ}$ & $\cdots$ & $\cdots$ & $\cdots$ & $\cdots$ \\
\hline$\ldots$ & $\ldots$ & $\ldots$ & $\ldots$ & 1 & 3 & 3 & 3 & 1 & $\cdots$ & $\cdots$ & . & \\
\hline$\ldots$ & $\dot{0}$ & $\cdots$ & . & 1 & 1 & 1 & $\cdots$ & $\cdots$ & & $\because \ddot{10}$ & & \\
\hline$\ldots$ & 12 & 12 & 12 & 12 & 1 & 1 & $\cdots$ & 7 & 12 & 12 & 12 & 1. \\
\hline$\cdots$ & & . & 5 & 5 & 1 & 1 & 1 & 1 & & $\cdots$ & $\cdots$ & \\
\hline & 7 & 7 & 7 & 5 & 1. & 1 & $\cdot \cdots$ & $\cdots$ & 7 & 7 & $\cdots$ & \\
\hline$\ldots$ & $\cdots$ & 7 & 5 & 2 & 2 & 2 & $\cdots$ & $\cdots$ & $\cdots$ & $\cdots$ & $\cdots$ & \\
\hline$\cdots$ & & $\cdots$ & $\cdots$ & 2 & 2 & 2 & 2 & $\ldots$ & $\cdots \cdots$ & $\cdots$ & $\cdots$ & \\
\hline$\cdots$ & 7 & .. & $\cdots$ & & 2 & $=$ & 2 & $\cdots$ & $\cdots$ & . & $\cdots$ & \\
\hline$\ldots$ & $\because$ & 7 & 5 & 2 & 2 & 2 & 2 & $\cdots$ & $\cdots$ & $\cdots$ & $\cdots$ & \\
\hline & 7 & 5 & 5 & 2 & 2 & 2 & & 1 & 10 & 10 & & \\
\hline & 7 & 5 & 5 & ? & 3 & 3 & 3 & 1 & 10 & 10 & 8 & \\
\hline & $\ldots$ & 7 & 7 & 5 & 1 & 1 & 10 & $\cdots$ & $\cdots$ & $\cdots$ & $\cdots$ & \\
\hline & $\ldots$ & 5 & 5 & 2 & 2 & & $\cdots$ & $\cdots$ & $\cdots$ & $\cdot$ & $\cdots$ & \\
\hline & & $\ldots$ & 5 & 5 & 3 & 3 & 3 & $\cdots$ & $\cdots$ & $\cdots$ & $\cdots$ & \\
\hline$\ldots$ & 7 & $\cdots$ & 6 & 1 & 1 & 1 & & . & $\cdots$ & $\cdots$ & $\cdots$ & \\
\hline$\ldots$ & . & 7 & 5 & 1 & 1 & 1 & 1 & & $\cdots$ & $\because$ & $\cdots \cdots$ & \\
\hline & $\cdots$ & $\cdot \cdot$ & 6 & 3 & 3 & 3 & 3 & 1 & $\cdots$ & 1 & 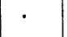 & \\
\hline & & $\cdots$ & 5 & 5 & $?$ & 2 & $\cdots$ & $\because$ & $\cdots$ & $\ldots$ & $\cdots$ & \\
\hline . & & & & 5 & 1 & 1 & $\cdots$ & $\cdots$ & & & $\cdots$ & \\
\hline$\cdots$ & 12 & 12 & 12 & 84 & 4 & 4 & $\cdots \cdots$ & $\cdots$ & 10 & 10 & $\cdots$ & \\
\hline & $\cdots$ & $\cdots$ & 6 & 1 & & $\because$ & $\cdots$ & 1 & 1 & $\cdots$ & $\cdots$ & \\
\hline$\cdots$ & $\cdots$ & $\cdots$ & 5 & 5 & 1 & 1. & $\cdots$ & $\cdots$ & $\cdots$ & 9 & $\cdot$ & \\
\hline & $\cdots$ & $\cdots$ & $\begin{array}{l}6 \\
7\end{array}$ & $\frac{1}{7}$ & 1 & $\cdots$ & $\cdots$ & $\cdots$ & 3 & & & \\
\hline 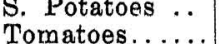 & 7 & 7 & -5 & 2 & 2 & $\ddot{2}$ & .. & $\ddot{7}$ & $\ddot{7}$ & 7 & $\ldots$ & \\
\hline & & $\ldots$ & & & & & 1 & 1 & 1 & $\cdots$ & $\cdots$ & \\
\hline & & & 5 & 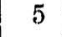 & 1 & 1 & . & $\ldots$ & ... & . & .. & \\
\hline
\end{tabular}


1. To be sown in open ground without transplanting. Plants have to be thinned out and given proper distance.

2. Sow on seed bed in the garden, and transplant to permanent place.

3. Make two sowings in open ground during the month.

4. Make three sowings in the open ground during the month.

5. Start in the greenhouse or hotbed, and plant out as soon as the ground is in good condition, and weather permits.

6. Sow in open ground as soon as it can be worked.

7. To be grown only in the greenhouse or hotbed.

8. Sow in cold frame, keep plants there over winter with a little protection; plant out in spring as soon as the ground can be worked.

9. To be sown in open ground and protected with litter over winter.

10. Plant in frame. When cold weather sets in, cover with sash and straw mats. Plants will be ready for use in December and January.

11. Plant out doors in prepared beds.

Sow every week in greenhouse or frame to have good succession.

Noте:-For the last planting of beans, sweet corn, kohlrabi, peas and radishes, or even tomatoes, take the earliest varieties just the same as for the first planting. 